\title{
Swampy rice lines for iron toxicity tolerance and yield components performance under inland swamp at Sorong, West Papua, Indonesia
}

\author{
AJANG MARUAPEY ${ }^{1}$, NOLADI WICAKSANA ${ }^{2}$, AGUNG KARUNIAWAN ${ }^{2}$, GUT WINDARSIH ${ }^{3}$, \\ DWINITA WIKAN UTAMI ${ }^{4, \bullet}$ \\ ${ }^{1}$ Faculty of Agriculture, Universitas Padjadjaran. Jl. Raya Bandung-Sumedang Km 21, Jatinangor, Sumedang 45363, West Java, Indonesia \\ ${ }^{2}$ Program of Plant Breeding, Agriculture Faculty of Agriculture, Universitas Padjadjaran. Jl. Raya Bandung-Sumedang Km 21, Jatinangor, Sumedang \\ 45363, West Java, Indonesia \\ ${ }^{3}$ Program of Biology, Faculty of Science, Universitas Islam Negeri Sultan Maulana Hasanuddin Banten. Jl. Syech Nawawi Al-Bantani, Andamu’i, Curug, \\ Serang City 42116, Banten, Indonesia \\ ${ }^{4}$ Indonesian Center of Biotechnology and Agricultural Genetic Resources for Research and Development. Jl. Tentara Pelajar 3A, Bogor 16111, West \\ Java, Indonesia. Tel.: +62-251-8337975, ’email: dwinitawikan@pertanian.go.id
}

Manuscript received: 19 September 2020. Revision accepted: 25 October 2020.

\begin{abstract}
Maruapey A, Wicaksana N, Karuniawan A, Windarsih G, Utami DW. 2020. Swampy rice lines performance for iron toxicity tolerance and yield components under inland swamp at Sorong, West Papua, Indonesia. Biodiversitas 21: 5394-5402. The extensification of sub-optimal lowland farming strategy is expected to support the increase of rice production. Based on the efforts, the development of tolerant rice varieties to Fe-toxicity to be used in the swampy land area is one of the approaches for increasing rice production. Currently, promising rice lines that are tolerant to Fe-toxicity has been developed using molecular breeding approach for inland swampy area. The objective of this research was to evaluate the performance of 15 promising rice lines that have various genetic backgrounds in inland swamp in Sorong, West Papua. The field experiment was conducted during the second rice planting season (August 2018 to February 2019) to evaluate the performance of the promising rice lines to the morpho-agronomic performance under the lowland swamp conditions. The trial was laid out in a Randomized Complete Block Design (RCBD) consisting of $4 \mathrm{~m} \times 5 \mathrm{~m}$ square plots, with $25 \mathrm{~cm} \times 25 \mathrm{~cm}$ planting distance and 3 replications. The results revealed that most of the lines had good performances on the Fe-toxicity tolerance, based on bronzing, root length, and biomass characters. The G1 line had the best performance on yield component characters, especially the panicle length. This line also had the highest grain yield $\left(6.15\right.$ ton.ha $\left.^{-1}\right)$ followed by the next promising line of G7 (5.92 ton.ha ${ }^{-1}$ ). The genetic performance of these lines showed that they contained IRT (Iron Regulation Transporter) alleles that contributed to partitioning the Fe tolerance mechanism.
\end{abstract}

Keywords: Fe-toxicity tolerant, inland swamp, promising lines of molecular breeding, yield characters

\section{INTRODUCTION}

The national food needs to keep increasing along with the increase of population. Meanwhile, one of the serious threats for national food security is the conversion of intensive rice fields into non-agriculture, especially for road infrastructure, airports, office buildings, and industry (Irawan 2005; Mulyani 2017). In facing climate change and extreme weather conditions, Indonesia needs to find ways to increase crop production (Naylor et al. 2007). Therefore, the strategy of utilizing the sub-optimal lands, such as swamps, becomes one of the solutions to increase national food production.

The swampland areas in Indonesia are classified into two main categories, i.e. tidal swamp and inland swamp. These two types of swamp are dominantly distributed in Sumatra, Kalimantan, Papua, and a small part in Sulawesi. Total swamp area in Indonesia is estimated to be 34 million ha, accounting for $18 \%$ of Indonesia's land area, of which 20.09 million ha $(60.2 \%)$ are tidal swamp and 13.30 million ha $(39.8 \%)$ are of inland swamp (Departement of Public Works 2009; Sulaiman et al. 2019). The inland swamp is a land area that has a puddle at least for three months throughout the year with a height of at least $50 \mathrm{~cm}$.
The use of inland swamp for agricultural development is termed as the rainwater swampland (Noor 2007). So, this type of land was characteristically flooded for a long period of time and the soil is basically muddy. Based on the water level and the length of puddle, an inland swamp in Indonesia consists of (a) a shallow rainwater swamp with a puddle height of $<50 \mathrm{~cm}$ for $<3$ months, (b) a middle inland swamp with a puddle height of $50-100 \mathrm{~cm}$ for $<6$ months, and (c) a deep inland swamp with a puddle height of $>100$ cm during $>6$ months (Widjaja et al. 1992).

The frequency of puddle occurs relatively long, so that the exposure of plants to iron occurs continuously. The iron $\left(\mathrm{Fe}^{2+}\right)$ toxicity is one of the important abiotic stresses which could decrease rice production. The results of evaluation of the tolerance level of some swamp rice varieties to $\mathrm{Fe}^{2+}$ toxicity showed that, in general, the rice plants experienced the symptom of sensitive moderate bronzing (score 3-4), such as in varieties of Inpara 3, IR42, Banyuasin, Batanghari, and Mahsuri. Among these varieties, Mahsuri variety showed the lowest bronzing score (Utami 2018).

The understanding of the Fe-toxicity mechanism showed that there are some different types of Fe-toxicity tolerance mechanisms in rice plants. Type I consists of the $\mathrm{Fe}$ exclusion from roots, and uses the aerenchyma-derived 
oxygen or the enzymatic activity to oxidize $\mathrm{Fe}^{2+}$ into $\mathrm{Fe}^{3+}$ which precipitates as Fe plaque at the root surface (Wu et al. 2014). This is considered a root-based mechanism. Type II consists of the shoot tolerance to a high Fe concentration, likely through the compartmentalization via storage within the inner cavity of ferritin proteins (Stein et al. 2009) or by the action of vacuolar transporters (Zhang et al. 2012). Meanwhile in Type III, the presence of an antioxidant system that detoxifies the reactive oxygen species produced via Fenton when $\mathrm{Fe}$ that presents in excess ( $\mathrm{Wu}$ et al. 2017). Types II and III are considered as shoot-based mechanisms.

Some of the genes involved in the mechanism of $\mathrm{Fe}$ absorption by rice plants include the IRT (Iron Regulator Transporter) transporter gene. The $\mathrm{Fe}^{2+}$ ions that have been absorbed will be transported by the protein that coded by $I R T$ gene to different parts of the plants, through the mechanism of $\mathrm{Fe}^{2+}$ partitioning so that the plants can be more tolerant to the excessive $\mathrm{Fe}^{2+}$ conditions (Rout et al. 2015). The molecular markers that linked to the OsIRT gene on rice (Oryza sativa, IRT) have been designed and used to assist the selection process to support the breeding programs for the swamp rice lines development. These molecular markers have been used for selecting the breeding lines derived from a crossing using the multi parents varieties to develop the Fe-tolerant rice lines.

The Marker Assisted Selection (MAS) application on molecular breeding approach can improve the precision of the selection based on these superior genes. Moreover, molecular breeding can also determine the direction of selection, for example, it can minimize the linkage drag of undesired insertion. However, molecular breeding can not stand alone, but it still needs to be completed by selection based on the phenotypes. The purpose of this study was to evaluate the agronomic performance, including yield and yield characters of the promising molecular breeding, the Fe-toxicity tolerant lines in the shallow rainwater inland swamps in Sorong, West Papua, Indonesia.

\section{MATERIALS AND METHODS}

\section{Genetic material}

Fifteen advanced promising rice lines developed from various genetic backgrounds (Table 1) were used in this experiment. The evaluation in different locations and different seasons could have significant information for fluctuations in yield and yield components characters due to variations in soil fertility, unpredictable rainfall, and the presence of other biotic and abiotic stresses.

To confirm the genotype profiles, the selected lines used were analyzed using the specific primer for IRT alleles, OsIRT1 (F: TCTTCCACCCTGAGCAGCTC; R: AACCTTGGAGACCAGTGCAG) (Utami et al. 2020).

\section{Agroecosystem of the testing location}

The experiment was conducted in a shallow inland swampland with a puddle height of $>100 \mathrm{~cm}$ in Makbalaim Village, Mayamuk Sub-district, Sorong District, West Papua Province, Indonesia (Figure 1). The field experiment was conducted during planting season-II, starting from August to November 2018.

The altitude of trial location is $285 \mathrm{~m}$ above sea level. The climatic condition at the field site is humid tropic. The rainfall average $2836.4 \mathrm{~mm}$ per year with the number of days $107-185$ rain. The average air temperature ranges between $25.09^{\circ} \mathrm{C}$ (minimum) and $27.15^{\circ} \mathrm{C}$ (maximum) with $87 \%$ air humidity. The average rainfall during experiment was $2809.25 \mathrm{~mm}$ per year with 210 days of rain and a wind speed of 4.17 Knots (Meteorology station Domine Edward Osok, Sorong City 2018).

\section{Soil characteristics of testing location}

The experiment was conducted in inland swamp condition with an alluvial soil type. The soil physical and chemical properties are shown in Table 2.

The soil texture was dominantly silty-clay. This soil has more fine particles so that it can hold water and nutrients better than the sandy soil type, but it can cause a lesser yield increase due to high nitrogen level (Ye et al. 2007). The organic material showed that $\mathrm{C}$-organic was low while $\mathrm{N}$-total was medium. The $\mathrm{C} / \mathrm{N}$ ratio also was categorized into medium. A low $\mathrm{C} / \mathrm{N}$ ratio condition tended to exhibit the net $\mathrm{N}$ mineralization, which affected the bioavailability of $\mathrm{N}$ mineral (Mohanty et al. 2010). In contrast, a high $\mathrm{C} / \mathrm{N}$ ratio will cause the exhibition of $\mathrm{N}$ immobilization, which prevents the $\mathrm{N}$ from being accessible to plants (White 2005).

Table 1. The genetic material used in this research and their parents for crossing

\begin{tabular}{ll}
\hline $\begin{array}{l}\text { Line } \\
\text { number }\end{array}$ & Parents crossing \\
\hline G1 & $\begin{array}{l}\text { Kao Daok Mali-105-9 / B13143-8-MR-3-KA-14 } \\
\text { // Inpara 5 }\end{array}$ \\
G2 & Setail / Inpara 2 // Code \\
G4 & B11844-MR-29-7-1 / Inpara 3 // Cisantana \\
G5 & B11844-MR-29-7-1 / Inpara 5 // Code \\
G6 & IR42 / Ciherang \\
G7 & Banyuasin / Ketankutuk \\
G8 & Siakraya / B13132-7-MR-1-KA-6 \\
G10 & Swarna Sub-1 / Mekongga \\
G11 & Swarna Sub-1 / Ciherang \\
G13 & Batanghari / Conde \\
G14 & Inpari 9 / Swarna Sub-1 \\
G16 & Cimelati / Inpara 3 // Inpari 9 / FR13A \\
G18 & Mekongga / Inpara 3 // Mekongga / Inpara 3 \\
G21 & IR64 Kebo / BR11 Sub-1 \\
G22 & Ciherang / Swarna Sub-1 // Ciherang /// Inpara 3 \\
G33 (IR64) & Negative control (sensitive to Fe-toxicity) \\
G34 (Mahsuri) & Positive control (tolerant to Fe-toxicity) \\
\hline
\end{tabular}



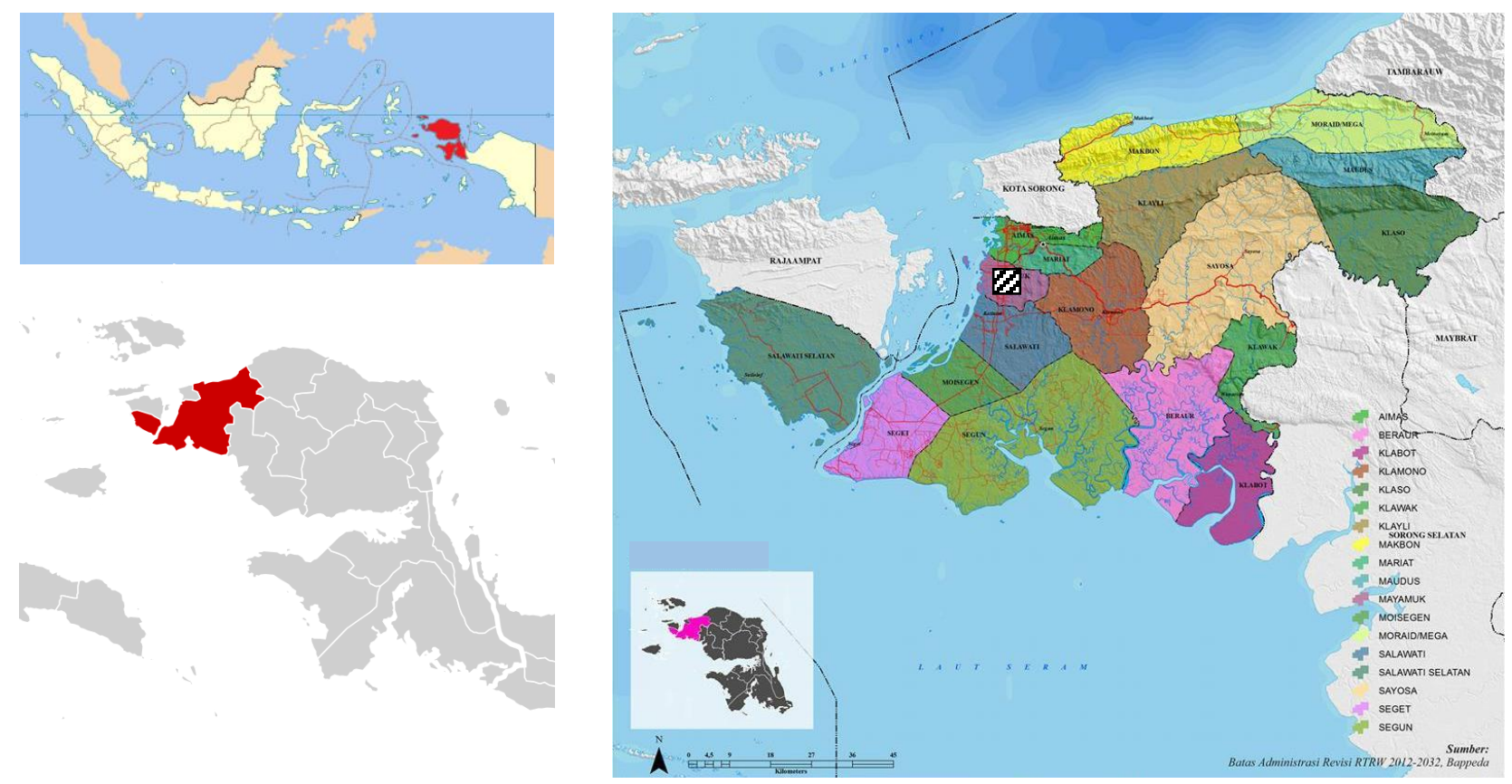

Figure 1. The map of field experiment location in Makbalaim Village (rectangle), Mayamuk Sub-district, Sorong District, West Papua Province, Indonesia

Table 2. Soil physical and chemical properties of testing location.

\begin{tabular}{|c|c|c|c|c|c|c|c|c|c|c|c|c|c|c|c|c|}
\hline \multicolumn{3}{|c|}{ Soil texture $(\%)$} & \multicolumn{3}{|c|}{ Organic material \% } & \multirow[t]{2}{*}{$\begin{array}{c}\text { pH } \\
\mathbf{H}_{2} \mathrm{O}\end{array}$} & \multicolumn{2}{|c|}{$\begin{array}{l}\text { HCL 25\% } \\
(\mathrm{mg} / 100 \mathrm{~g})\end{array}$} & \multicolumn{4}{|c|}{$\begin{array}{l}\text { Sample soil dryness } \\
\left(105^{\circ} \mathrm{C}\right)\end{array}$} & \multirow[t]{2}{*}{$\begin{array}{c}\mathbf{F e} \\
(\mathbf{p p m})\end{array}$} & \multicolumn{3}{|c|}{$\begin{array}{c}\text { Total } \\
\left(\mathrm{NHO}_{3}\right) \%\end{array}$} \\
\hline Sand & Silt & Clay & C org & $\mathbf{N}$ total & $\mathrm{C} / \mathrm{N}$ & & $\mathrm{P}_{2} \mathrm{O}_{5}$ & $\mathbf{K}_{2} \mathbf{O}$ & $\mathbf{C a}$ & Mg & $\mathbf{K}$ & $\mathbf{N a}$ & & $\mathrm{Fe}$ & $\mathbf{S}$ & Piryt \\
\hline 0 & 45 & 55 & 2.28 & 0.26 & 19 & 4.6 & 176 & 11 & 9.75 & 8.45 & 0.13 & 30.35 & 367 & 7.24 & 0.01 & 0.02 \\
\hline 1 & 42 & 58 & 4.28 & 0.23 & 18 & 4.6 & 139 & 9 & 9.79 & 8.52 & 1.10 & 0.33 & 368 & 6.60 & 0.01 & 0.02 \\
\hline 2 & 41 & 58 & 3.38 & 0.25 & 17 & 4.7 & 128 & 8 & 9.93 & 8.47 & 0.10 & 0.35 & 477 & 7.38 & 0.01 & 0.02 \\
\hline
\end{tabular}

Source: Soil analysis results by Soil Research Laboratory of Indonesia Soil Research Institute, Bogor, West Java, Indonesia.

\section{Observed parameters}

The experiment was conducted in a randomized block design, with 3 replications and 17 genotypes as treatments, two of them were a sensitive control variety (IR64) and a tolerant control variety (Mahsuri). The experimental unit was a plot measuring $4 \mathrm{~m} \times 5 \mathrm{~m}$. The planting was conducted with a spacing of $25 \mathrm{~cm} \times 25 \mathrm{~cm}$ after the seedlings were 21 days old. The seeds were planted one seedling per hole. The fertilizers used were organic and inorganic fertilizers. The organic cow-manure was used as basic fertilizer and given after the soil was processed with a dose of $5 \mathrm{~kg}$ per plot (2.5 tons.ha- $\left.{ }^{-1}\right)$. An inorganic fertilizer used was NPK Phonska with a dose of $100 \mathrm{~kg} \cdot \mathrm{ha}^{-1}$. Each fertilizer was given 2 times, first at 14 DAP (days after planting) and the second fertilizer at 30 DAP, on a half dosage. The irrigation was done intermittently for 4 wet days and 4 dry days. The weed control was conducted mechanically by using porcupines at 4 DAP (1-month-old plants) and 8 DAP (2 months old plants). Furthermore, the pest control was carried out according to the field conditions with the inorganic pesticides, Regent 80 to control the main pest, like Nilaparvata lugens and Scirpophaga sp.
Scoring the bronzing symptoms for the Fe-toxicity parameters was referring to the SES method, shown in Table 3. The agronomic characters, yield component, and grain yield characters were observed according to Standard Evaluation System for Rice (IRRI 2014).

\section{Genotype analysis \\ DNA isolation}

DNA isolation was performed using the CTAB method according to Doyle \& Doyle (1987). The plant leaves were ground in liquid nitrogen by a tissue lyser. A sample was added with $750 \mu \mathrm{L}$ Cetyltrimethyl Ammonium Bromide $(\mathrm{CTAB})$ buffer and incubated in $65^{\circ} \mathrm{C}$ for $30 \mathrm{~min}$. This suspension was then added with $750 \mu \mathrm{L}$ CI (chloroform: isoamyl alcohol $=24: 1$ ) and centrifuged at 10,000 rpm for 15 minutes. The supernatant was moved into a new tube and then added with $50 \mu \mathrm{L} \mathrm{Na}$-acetate $2 \mathrm{M}$ pH 5.2 and $1 \mathrm{~mL}$ absolute ethanol and incubated overnight at $-20^{\circ} \mathrm{C}$. After freezing overnight, it was centrifuged at $10,000 \mathrm{rpm}$ for 15 minutes. A pellet was washed with $500 \mu \mathrm{L} 70 \%$ alcohol and centrifuged at $10,000 \mathrm{rpm}$ for 5 minutes. A dried pellet was added with $50 \mu \mathrm{L} 1 \times \mathrm{TE}$ and $10 \mu \mathrm{L}$ of $10 \mathrm{ng} . \mu \mathrm{L}^{-1}$ RNase and incubated at $37^{\circ} \mathrm{C}$ for one hour. The inactivation 
of RNase was performed by incubation at $65^{\circ} \mathrm{C}$ for 15 minutes. DNA quality was tested by electrophoresis on $0.8 \%$ agarose gel in $1 \times \mathrm{TAE}$ buffer at 100 volts for 60 minutes, then visualized using UV light (BioRad, USA). The DNA quantity was determined using the NanoDrop 2000c Spectrophotometer (Thermo Scientific, USA).

\section{PCR analysis}

PCR analysis was included in the markers selection and the amplification of DNA fragment. In the markers selection, PCR analysis was performed in a total volume of $10 \mu \mathrm{L}$ containing $4 \mu \mathrm{L}$ DNA (10 ng), $0.5 \mu \mathrm{L}$ primers-F 2.5 pmol, $0.5 \mu \mathrm{L}$ primers-R $2.5 \mathrm{pmol}$, and $5 \mu \mathrm{L}$ of KAPA. PCR conditions were pre-PCR at $94^{\circ} \mathrm{C}$ for 5 minutes,

denaturation at $94^{\circ} \mathrm{C}$ for 45 seconds, annealing at $55^{\circ} \mathrm{C}$ for 1 minute, elongation at $72^{\circ} \mathrm{C}$ for a minute, and post-PCR at $72^{\circ} \mathrm{C}$ for 7 minutes. PCR process was performed for 35 cycles. PCR products were analyzed using an electrophoresis on agarose gel $2 \%$ in a buffer solution of $1 \times$ TAE buffer (40 mM Tris-acetate, $1 \mathrm{mM}$ EDTA) at 50 volts for 60 minutes. DNA bands in agarose were visualized with UV light. DNA fragments of selected Fe-tolerant rice (41 populations) were amplified using 14 selected primers related to rice grain quality. PCR reactions were conducted in same procedure as in markers selection, but an annealing temperature was adjusted for optimization temperature of each primer for 1 minute. DNA visualization was subsequently measured by GelQuant.NET 3.5 to determine the size of the base of each DNA band.

\section{Data analysis}

The data obtained were analyzed statistically using the analysis of variance (ANOVA) and the mean difference between each test line with the check varieties was determined using the Least Significant Increase (LSI) (Peterson 1994) at a 5\% confidence level.

\section{RESULTS AND DISCUSSION}

\section{Fe-toxicity tolerance level}

The ANOVA of the Fe-toxicity tolerant characters showed a significant result $(<0.001)$ only for the root length character. The ANOVA results revealed that all the lines tested have the same performances in the bronzing score and biomass, but the different performance on the length of roots.

The F toxicity tolerance character's scores of the total of 15 lines, as compared to the check varieties at the vegetative stage were varied, ranged from 1 to 5 , while at the generative stage, there was indication of the recovery of the $\mathrm{Fe}$ tolerance performance shown by the decreasing bronzing scores with a range from 1 to 3 (Table 4). There were 10 lines that had a steady tolerance level on both vegetative and generative stages, i.e. G1, G2, G4, G5, G7, G8, G10, G11, G21, and G22.

The performance of root lengths of the lines shown in Table 4 indicated that G18 and G5 had the best performance on root length, as showed on the LSI mean difference, they had close performance to the positive check variety, G34. They had the root length reached up to $27.2^{\mathrm{ab}} \mathrm{cm}$ and $25.2^{\mathrm{bc}} \mathrm{cm}$, respectively, while $28.1^{\mathrm{a}} \mathrm{cm}$ for G34. This indicated that the tested plants could grow and develop well due to their long roots that can absorb nutrients properly. Koesrini et al. (2018) also reported that based on their observation in tidal swampland, the rice plants that intolerant to iron toxicity had a little short and dark brown roots, so the nutrient absorption was poor and had affected on a short plant height. Nevertheless, the correlation analysis showed that there was no correlation (coefficient correlation: 0.09) between bronzing score to root length.

The biomass performance of the rice lines tested showed that all lines had higher biomass than the negative control plant (Fe sensitive variety), G33. It indicated that all lines had a better performance on Fe-toxicity than G33. Nevertheless, several lines had lower biomass than the positive control plant, G34. The G5 line had the best on both root length and biomass performance, while G11 and G21 had the finest biomass performance. There was significant correlation between bronzing score to weight of biomass (coefficient correlation: $-0,58^{* *}$ ). It seems indicated that the tolerance plants (low bronzing score) have higher biomass weight. While the correlation between root length and biomass was also significant (coefficient correlation: $0.59^{* *}$ ), so that means the root length and biomass were significant parameters for Fe tolerance but not directly correlated to bronzing score. The selected lines based on bronzing score, root length and biomass parameters were showed as the worthy promising lines since they had a good response tolerant to Fe-toxicity.

Table 3. The tolerance score of Fe-toxicity in rice plants.

\begin{tabular}{lll}
\hline Score & Plants symptoms & Tolerance level \\
\hline 1 & Normal growth and tillers & Highly Tolerant (HT) \\
3 & Growth and tillers are somewhat normal, dark brownish-red, purple or orange yellowish leaves & Tolerant (T) \\
5 & Stunted growth and tillers, many leaves are reduced & Moderate Tolerant (MT) \\
7 & Growth and tiller, generally bronzing leaves or dies & Sensitive (S) \\
9 & All plants almost die or die & Highly Sensitive (HS) \\
\hline Note: Scoring symptoms of Fe-toxicity observed at 1 DAP and 8 DAP with referring to the SES method (IRRI 2014). Score 1 = highly \\
tolerant, $3=$ tolerant, 5 = moderate tolerant, 7 = sensitive, and 9 = highly sensitive.
\end{tabular}


Table 4. The Fe-toxicity performance of rice lines tested

\begin{tabular}{|c|c|c|c|c|}
\hline \multirow[b]{2}{*}{ Lines } & \multicolumn{2}{|c|}{ Bronzing score } & \multirow{2}{*}{$\begin{array}{l}\text { Root } \\
\text { length } \\
\text { (cm) }\end{array}$} & \multirow[b]{2}{*}{$\begin{array}{l}\text { Biomass } \\
\text { (g) }\end{array}$} \\
\hline & $\begin{array}{l}\text { Vegetative } \\
\text { stage }\end{array}$ & $\begin{array}{l}\text { Generative } \\
\text { stage }\end{array}$ & & \\
\hline G1 & $1(\mathrm{HT})$ & $1(\mathrm{HT})$ & $22.4^{\mathrm{de}}$ & 835.3 \\
\hline $\mathrm{G} 2$ & $3(\mathrm{~T})$ & $1(\mathrm{HT})$ & $24.9^{b c d}$ & 714.2 \\
\hline G4 & $1(\mathrm{HT})$ & $1(\mathrm{HT})$ & $21.4^{\mathrm{ef}}$ & 832.2 \\
\hline G5 & $1(\mathrm{HT})$ & $1(\mathrm{HT})$ & $25.2^{\mathrm{bc}}$ & 865.9 \\
\hline G6 & 5 (MT) & $3(\mathrm{~T})$ & $19.6^{\mathrm{fg}}$ & 779.3 \\
\hline G7 & $1(\mathrm{HT})$ & $1(\mathrm{HT})$ & $20.5^{\mathrm{efg}}$ & 876.7 \\
\hline G8 & $1(\mathrm{HT})$ & $1(\mathrm{HT})$ & $18.6^{\mathrm{g}}$ & 827.7 \\
\hline G10 & $1(\mathrm{HT})$ & $1(\mathrm{HT})$ & $22.8^{\text {cde }}$ & 874.0 \\
\hline G11 & $1(\mathrm{HT})$ & $1(\mathrm{HT})$ & $15.4^{\mathrm{h}}$ & $1,403.7$ \\
\hline G13 & 5 (MT) & $3(\mathrm{~T})$ & $22.5^{\mathrm{de}}$ & 739.5 \\
\hline G14 & $5(\mathrm{MT})$ & $3(\mathrm{~T})$ & $19.7^{\mathrm{fg}}$ & 719.2 \\
\hline G16 & 3-5 (MT) & $3(\mathrm{~T})$ & $20.9^{\text {efg }}$ & 690.6 \\
\hline G18 & $5(\mathrm{MT})$ & $3(\mathrm{~T})$ & $27.2^{\mathrm{ab}}$ & 683.1 \\
\hline G21 & $3(\mathrm{~T})$ & $3(\mathrm{~T})$ & $19.9^{\mathrm{fg}}$ & 844.6 \\
\hline $\mathrm{G} 22$ & $1-3(\mathrm{~T})$ & $1(\mathrm{HT})$ & $24.1^{\mathrm{cd}}$ & 819.2 \\
\hline G33 & 5 (MT) & 5 (MT) & $22.7^{\text {cde }}$ & 558.5 \\
\hline G34 & $1-3(\mathrm{~T})$ & $1(\mathrm{HT})$ & $28.1^{\mathrm{a}}$ & 834.3 \\
\hline
\end{tabular}

Note: $\mathrm{HT}=$ highly tolerant; $\mathrm{T}=$ tolerant; $\mathrm{MT}=$ moderate tolerant

During Fe-toxicity, the direct effect was shown on the tiny brown spots which appear on the leaf tips and spread to the leaf base, and then will result in the reddish-colored leaves followed by the drying of leaves, this condition is known as a leaf bronzing process and most recognized as the morphological symptom of Fe-toxicity (Becker and Asch 2005). The leaf bronzing typically appears first in the older leaves with higher transpiration rates (Aung et al. 2018). Besides the leaf performance, the Fe-toxicity stress will also affect the root and shoot performances (Stein et al. 2019). The leaf bronzing, root length, and weight of biomass were used as the parameters of the rice lines tolerance to Fe-toxicity.

\section{Agronomic characters and yield components}

The ANOVA showed the significant $(<0.001)$ effect of rice genotypes on all yield component characters, except the total number of grain per panicle. The ANOVA results revealed that all the lines tested gave different performances on agronomic and yield component characters. These results also indicated that this experiment in inland swamp could be screening the Fe toxicity tolerance performance of rice lines tested. So, it could be also possible for selecting the best performance lines on agronomy and yield component characters.

The ANOVA results showed that all characters among all tested rice were significantly $(\mathrm{P}<0.01)$ different, except on a total amount of grain per panicle. This result became obvious in a high CV (\%) for a total number of grains per panicle $(10.22 \%)$, which contained two characters, a number of filled grain (13.96\%) and a number of empty grain $(36.94 \%)$, which was the highest for all examined traits. The coefficients of variation $(\mathrm{CV})$ are a precision measure in experiments that been done.

Further, the results of testing for all lines evaluated showed that there were diverse performances on some characters (Table 5). The plant height performance dominated on $>60 \mathrm{~cm},>80 \mathrm{~cm}$, and $<120 \mathrm{~cm}$ at 4,6 , and 8 WAP, respectively. All the lines tested had a date of maturity less than 100 days, except for G21 and G22. Meanwhile, for a yield component, the G6 line had the longest panicle (PL) which reached $25.9 \mathrm{~cm}$. The $\mathrm{G} 8$ line had the biggest number of filled grain (N-FG), while the G6 line had the smallest number of empty grain (N-EG) and the G11 line had the biggest number of total grain $(\mathrm{N}$ TG) per panicle.

\section{Grain yield evaluation}

The ANOVA results of grain yield characters showed a significant $(<0.001)$ different on all rice tested. Those ANOVA results revealed that all the lines tested gave different performances on the thousand-grain weight and yield characters. These results indicated that an inland swamp that used as the evaluation site gives a different selection effect to the lines tested, so that it could be possible to select the lines which had the best performance on agronomic and yield component characters. Table 8 showed that the performance of grain weight and yield characters have a significantly different $(\mathrm{P}<0.01)$ among all the lines tested.

The post hoc test showed significantly different performances of tested rice lines on some characters (Table 6 ). The best line for thousand-grain weight was G11, which produced 21.40 grams. Meanwhile, for a total yield per plot, the line of G1 showed the best performance which gave a total of $12.30 \mathrm{~kg} /$ per plot or could be converted as 6.2 ton. $^{-1} \mathrm{a}^{-1}$, and the second next better-selected line was G7 which had a yield of $11.83 \mathrm{~kg} /$ per plot or could be converted as 5.9 ton.ha ${ }^{-1}$.

The experiment was conducted in an inland swamp area which categorized as non-tidal swamp. This area is a river flood plain that receives no effect from the sea tides (Irawati et al. 2015). The main problem of an inland swamp is water puddle, while the soil fertility is not dominant in affecting the rice cultivation (Noor 2007). In general, the level of soil fertility in an inland swamp is higher than in a tidal land. In puddle condition, the Fe-toxicity often emerges and inhibits the plant growth, this condition causes the rice yield to decline by up to $90 \%$ in a high Fe level in the Yellow Red Podsolik soil type in Lampung, Sumatra (Suhartini 2004).

During a rainy season, non-tidal swamp areas are flooded by the river and the floodwater doesn't recede until dry season. The water volume in non-tidal swamp significantly will depend on rainfall; it is deeper in rainy season and will gradually decrease during dry season. Therefore, the planting usually will start at the end of rainy season or depend on the water level in the field. The main problem faced by the farmers was due to the unstable water level and unpredicted weather. The common situation in the field was high flooding prior to planting and extreme drought during the reproductive stage. This situation had caused the farmers need to adjust their planting time and to reconsider the use of proper cultivar combined with some improved cultivation techniques (Sulaiman et al. 2019). 
Table 5. The results of LSI test for further analysis of agronomic and yield component characters on the rice lines tested

\begin{tabular}{|c|c|c|c|c|c|c|c|c|c|}
\hline \multirow{2}{*}{ Lines } & \multicolumn{3}{|c|}{ Plant Height (cm) } & \multirow{2}{*}{ DF } & \multirow{2}{*}{ DM } & \multirow{2}{*}{ PL } & \multirow{2}{*}{ N-FG } & \multirow{2}{*}{ N-EG } & \multirow{2}{*}{ N-TG } \\
\hline & 4 WAP & 6 WAP & 8 WAP & & & & & & \\
\hline G1 & $57.11^{\mathrm{a}}$ & 81.44 & $110.55^{\mathrm{a}}$ & $75^{\mathrm{ab}}$ & $90^{\mathrm{fg}}$ & $27.23^{\mathrm{ab}}$ & $163.80^{\mathrm{ab}}$ & $36.40^{\mathrm{ab}}$ & $200.2^{\text {efg }}$ \\
\hline $\mathrm{G} 2$ & 50.74 & 72.67 & 106.55 & $75^{\mathrm{ab}}$ & $85^{\mathrm{h}}$ & $26.70^{\mathrm{bcd}}$ & $169.80^{\mathrm{ab}}$ & $36.80^{\mathrm{ab}}$ & $204.3^{\mathrm{g}}$ \\
\hline G4 & $60.41^{\mathrm{a}}$ & 84.22 & $118.55^{\mathrm{a}}$ & $70^{\mathrm{ab}}$ & $87^{\text {gh }}$ & $26.77^{b c}$ & $157.67^{\mathrm{ab}}$ & $50.40^{\mathrm{a}}$ & $207.9^{\mathrm{bcd}}$ \\
\hline G5 & $62.04^{\mathrm{a}}$ & $85.78^{a}$ & $116.15^{\mathrm{a}}$ & $72^{\mathrm{ab}}$ & $87^{\text {gh }}$ & $26.76^{b c}$ & $157.73^{\mathrm{ab}}$ & $60.40^{\mathrm{a}}$ & $221.5^{\mathrm{efg}}$ \\
\hline G6 & $61.52^{\mathrm{a}}$ & 84.74 & $113.15^{\mathrm{a}}$ & $62^{\mathrm{ab}}$ & $81^{\mathrm{i}}$ & $25.97^{\text {cde }}$ & $207.67^{a}$ & $24.00^{\mathrm{ab}}$ & $231.4^{\mathrm{bc}}$ \\
\hline G7 & $60.07^{a}$ & 82.78 & $116.37^{\mathrm{a}}$ & $66^{\mathrm{ab}}$ & $80^{\mathrm{ij}}$ & $26.15^{\mathrm{cd}}$ & $212.27^{\mathrm{a}}$ & $25.60^{\mathrm{ab}}$ & $240.07^{\mathrm{a}}$ \\
\hline G8 & $61.29^{\mathrm{a}}$ & 83.63 & $111.82^{\mathrm{a}}$ & $65^{\mathrm{ab}}$ & $95^{\mathrm{de}}$ & $25.99^{\text {cde }}$ & $218.00^{\mathrm{a}}$ & $25.73^{\mathrm{ab}}$ & $243.8^{\text {cdefg }}$ \\
\hline G10 & $61.59^{\mathrm{a}}$ & $87.26^{\mathrm{a}}$ & $117.59^{\mathrm{a}}$ & $80^{\mathrm{b}}$ & $94^{\text {de }}$ & $26.96^{b c}$ & $199.60^{\mathrm{a}}$ & $30.40^{\mathrm{ab}}$ & $236.3^{\mathrm{ab}}$ \\
\hline G11 & $64.44^{\mathrm{a}}$ & $90.07^{\mathrm{a}}$ & $130.19^{\mathrm{a}}$ & $79^{b}$ & $94^{\text {de }}$ & $27.26^{\mathrm{ab}}$ & $207.90^{\mathrm{a}}$ & $64.00^{\mathrm{a}}$ & $270.7^{\text {cdef }}$ \\
\hline G13 & $60.63^{a}$ & $90.11^{\mathrm{a}}$ & $120.37^{\mathrm{a}}$ & $79^{b}$ & $96^{\mathrm{d}}$ & $25.67^{\mathrm{de}}$ & $179.87^{\mathrm{ab}}$ & $47.13^{\mathrm{a}}$ & $227.53^{\mathrm{fg}}$ \\
\hline G14 & $60.22^{\mathrm{a}}$ & $86.63^{a}$ & $117.44^{\mathrm{a}}$ & $81^{\mathrm{b}}$ & $92^{e f}$ & $26.24^{\text {bcd }}$ & $150.53^{\mathrm{ab}}$ & $66.80^{\mathrm{a}}$ & $218.8^{\text {defg }}$ \\
\hline G16 & $62.18^{\mathrm{a}}$ & $85.30^{\mathrm{a}}$ & $120.82^{\mathrm{a}}$ & $77^{\text {tn }}$ & $100^{c}$ & $26.20^{\text {bcd }}$ & $175.90^{\mathrm{ab}}$ & $67.80^{\mathrm{a}}$ & $243.3^{\text {cdef }}$ \\
\hline G18 & $63.04^{\mathrm{a}}$ & $88.33^{\mathrm{a}}$ & $118.44^{\mathrm{a}}$ & $85^{\mathrm{ab}}$ & $95^{\mathrm{de}}$ & $25.11^{\mathrm{e}}$ & $163.90^{\mathrm{ab}}$ & $65.33^{\mathrm{a}}$ & $235.6^{\mathrm{efg}}$ \\
\hline G21 & $63.45^{\mathrm{a}}$ & $93.15^{\mathrm{a}}$ & $133.67^{\mathrm{a}}$ & $80^{\mathrm{b}}$ & $104^{\mathrm{a}}$ & $26.46^{\mathrm{bcd}}$ & $180.10^{\mathrm{ab}}$ & $79.07^{\mathrm{a}}$ & $250.3^{\mathrm{fg}}$ \\
\hline $\mathrm{G} 22$ & $39.48^{\text {tn }}$ & 75.70 & $114.03^{\mathrm{a}}$ & $89^{\mathrm{b}}$ & $104^{\mathrm{a}}$ & $25.06^{\mathrm{e}}$ & $157.90^{\mathrm{ab}}$ & $69.20^{\mathrm{a}}$ & $234.3^{\text {cdef }}$ \\
\hline G33 ${ }^{\text {(a) }}$ & 53.63 & 84.82 & 110.07 & 79 & $87^{\mathrm{gh}}$ & $24.04^{\mathrm{f}}$ & $114.93^{b}$ & 90.93 & $214.9^{\text {cdefg }}$ \\
\hline G34 (b) & 66.11 & 93.26 & 136.89 & 94 & $104^{a}$ & $27.97^{\mathrm{a}}$ & $169.07^{\mathrm{ab}}$ & 43.07 & $208.1^{\text {bcde }}$ \\
\hline
\end{tabular}

Note: $\quad \mathrm{WAP}=$ Week After Planting, $\mathrm{DF}=$ date to flowering, $\mathrm{DM}=$ date to maturity, $\mathrm{PL}=$ panicle length, $\mathrm{N}-\mathrm{FG}=$ number filled grain per panicle, $\mathrm{N}-\mathrm{EG}=$ number empty grains per panicle, $\mathrm{N}-\mathrm{TG}=$ total amount of grain per panicle

Table 6. The post hoc LSI test for thousand-grain weight (TGW) and yield characters of the rice lines tested

\begin{tabular}{|c|c|c|c|}
\hline \multirow{2}{*}{ Lines } & \multirow{2}{*}{ TGW (g) } & \multicolumn{2}{|l|}{ Yield } \\
\hline & & (kg/plot) & $\left(\right.$ ton.ha $\left.{ }^{-1}\right)$ \\
\hline G1 & $18.97^{\mathrm{efg}}$ & $12.30^{\mathrm{ab}}$ & 6.15 \\
\hline $\mathrm{G} 2$ & $17.43^{\mathrm{g}}$ & $7.07^{\mathrm{ab}}$ & 3.53 \\
\hline G4 & $22.33^{b c d}$ & $8.53^{\mathrm{ab}}$ & 4.27 \\
\hline G5 & $19.07^{\text {efg }}$ & $8.67^{\mathrm{ab}}$ & 4.33 \\
\hline G6 & $22.60^{\mathrm{bc}}$ & $6.43^{\mathrm{ab}}$ & 3.22 \\
\hline G7 & $26.47^{\mathrm{a}}$ & $11.83^{\mathrm{ab}}$ & 5.92 \\
\hline G8 & $19.53^{\text {cdefg }}$ & $10.80^{\mathrm{ab}}$ & 5.40 \\
\hline G10 & $24.43^{\mathrm{ab}}$ & $10.97^{\mathrm{ab}}$ & 5.48 \\
\hline G11 & $21.40^{\text {cdef }}$ & $10.27^{\mathrm{ab}}$ & 5.13 \\
\hline G13 & $18.57^{\mathrm{fg}}$ & $5.97^{\mathrm{b}}$ & 2.98 \\
\hline G14 & $19.20^{\operatorname{defg}}$ & $6.37^{\mathrm{ab}}$ & 3.18 \\
\hline G16 & $20.73^{\text {cdef }}$ & $5.27^{\mathrm{b}}$ & 2.63 \\
\hline G18 & $19.03^{\mathrm{efg}}$ & $6.73^{\mathrm{ab}}$ & 3.37 \\
\hline G21 & $18.23^{\mathrm{fg}}$ & $7.73^{\mathrm{ab}}$ & 3.87 \\
\hline $\mathrm{G} 22$ & $20.83^{\text {cdef }}$ & $10.60^{\mathrm{ab}}$ & 5.30 \\
\hline G33 (a) & $19.73^{\text {cdefg }}$ & 5.87 & 2.93 \\
\hline G34(b) & $21.87^{\text {bcde }}$ & 3.03 & 2.05 \\
\hline
\end{tabular}

Based on the results of field experiment, it showed that there were variations of Fe-toxicity tolerance responses on the rice lines tested. There was a wide variation in tolerance, which depended on the stress duration, strength, and plant development stage. Some genotypes might show the contrast performances depending on how and the location of experiments accomplished. The root is a part of plant which interacted directly with the soil performance, including the toxic $\mathrm{Fe}^{2+}$ level contained in the soil. The exposure of $\mathrm{Fe}^{2+}$ excess affected roots and continued to severe reduction of chlorophyll concentration in the leaf as will be shown as the bronzing spot. Nevertheless, there was no reduction in the tolerant one (Stein et al. 2019).
The previous research showed that (1) photosynthesis is affected by Fe-toxicity (Müller et al. 2017); it is known that the $\mathrm{Fe}$ uptake genes are down-regulated upon a high $\mathrm{Fe}$ treatment (Finatto et al. 2015); and that early (3 days) and late (3 weeks) Fe-toxicity responses are quite different in both roots and shoots (Quinet et al. 2012). However, the molecular mechanisms associated with tolerant and sensitive genotypes are a lot of underexplored. The lines evaluated are known contained the OsIRT allele gene which plays a role in regulating $\mathrm{Fe}$ uptake and transport in the genome of rice plants so that plants are tolerant. Nugraha and Rumanti (2017) confirmed the availability of rice plants giving a good production in a swampland with the iron toxicity condition depends on the condition of environment and the mechanism of plants in absorbing iron. One of the Fe-toxicity effects can be seen when the rice plant entering the end of the vegetative stage or the initial generative stage. The Fe-toxicity inhibits the formation of panicles and also the number of grains in each panicle (Singh et al. 1992). The Fe-toxicity also causes the plants to be sterile or disrupt the flowering (Virmani 1977). Virmani (1977) and Suhartini (2004) also reported that a decrease in the rice production was caused by iron toxicity, especially in an inland swamp, such as in Taman Bogo, Lampung, South Sumatera reached up to $70 \%$ loss yield production for intolerant varieties, while for tolerant varieties reached up to $30 \%$. So, the tolerant rice varieties that adaptive in a specific swamp land condition become one of important technology components to overcome the problems in the swampland agroecosystem (Kustianto 2009).

Other parameters of the Fe-toxicity tolerant are the performance of root and the biomass of plant, since their performances indicated the ability of plant to regulate the toxic effect of $\mathrm{Fe}^{2+}$. As examined on the material genetic used, all the lines used in this experiment have selected by 
using the OsIRT1 marker gene. This gene plays a role in strategy I of the Fe tolerance mechanisms (Bennett et al. 2011; Rout et al. 2015), which transport $\mathrm{Fe}^{2+}$ from the root epidermal tissue runs through the plasma membrane into the cytosol (Rout et al. 2015). Vert et al. (2001) mentioned that the IRTI gene contributes to the partitioning of $\mathrm{Fe}^{2+}$ mechanism to several parts of plant, from root to other parts of plant so that the plants can be more tolerant in the $\mathrm{Fe}^{2+}$ excess condition.

The rice varieties for a swampy area are generally tall and grow rapidly, have strong culms and medium growth duration, and tolerant to abiotic stresses such as soil acidity, Fe-toxicity, and salinity (Harahap and Silitonga 1998). The plant height is one of the criteria for the selection of rice plants, but it indirectly related to the yield. The plant height has a correlation of negative direct effect on grain yield but positive indirect effect through a number of productive tillers per hill (Hairmansis et al. 2010). Based on the observation of rice lines tested during the generative stage, especially when the panicles are formed, the lines tested start to be attacked by the stem borer pest. The impact of this condition, it causes the seed filling process to be hampered due to the damage to the plant stem so that it produces un-hulled rice. The empty grain will effect the rice yield. This is as reported by Ariati et al. (2016), stating that a higher percentage number of empty grain affected a lower rice yield. The empty grain shows the inability of plants to fill the grains of plants. The agronomic and yield components evaluation showed that G8 has the highest number of filled grain, with the plant height of $111.82 \mathrm{~cm}$, the days to flowering of 65 days, and the days to maturity of 95 days.

The evaluation of grain yield showed that G1 line has the highest yield $\left(6.15\right.$ t.ha $\left.^{-1}\right)$ but not for TGW character. This is related to Harmansis et al. (2010) stated that TGW rarely affected the grain yield. The line of G1 showed the longest panicle length (PL) comparing all the lines tested. The panicle length and grain yield showed a positive association to the Indica inbred ecotypes ( $\mathrm{Li}$ et al. 2019). The second rank on the yield characters was G7 line that has a yield of 5.92 t.ha $^{-1}$. This line has the days to flowering (DF) and the days to maturity (DM) shorter than G1 line. Both G1 and G7 lines are included as Indica inbreds, since derived from the Indica parents. The performance of field experiments, G1, and G7 lines are shown in Figure 2. The two of the selected lines, G1 and G7, probably could adapt to the unstable water fluctuation in the inland or non-tidal conditions, as a major problem are high flooding in rainy season and drought in dry season.

The development of swamp rice cultivation would be beneficial to support the national rice sufficiency in Indonesia. However, many challenging constraints, both on farm and off farm, in the promising rice lines tested at an inland swamp in Sorong, West Papua revealed that the most of lines show a steady tolerant, both on vegetative and generative stages, based on bronzing, root length and biomass characters. The agronomic and yield components evaluation showed that G7 line has the highest number of filled grain, while G1 line has the highest yield and panicle length characters. The selected lines would be valuable as the candidates of swampy rice varieties, especially for an inland swamp area.

\section{Genotype performances}

The genotype performance of the rice lines detected using the specific primer linked to the OSIRT gene showed that the allelic variation ranged from $200 \mathrm{bp}$ to $300 \mathrm{bp}$ (Figure 3). The lowest size allele indicated the medium tolerance (MT) and tolerance (T), while the upper size alleles seem closely linked to Fe-sensitive/susceptible trait.

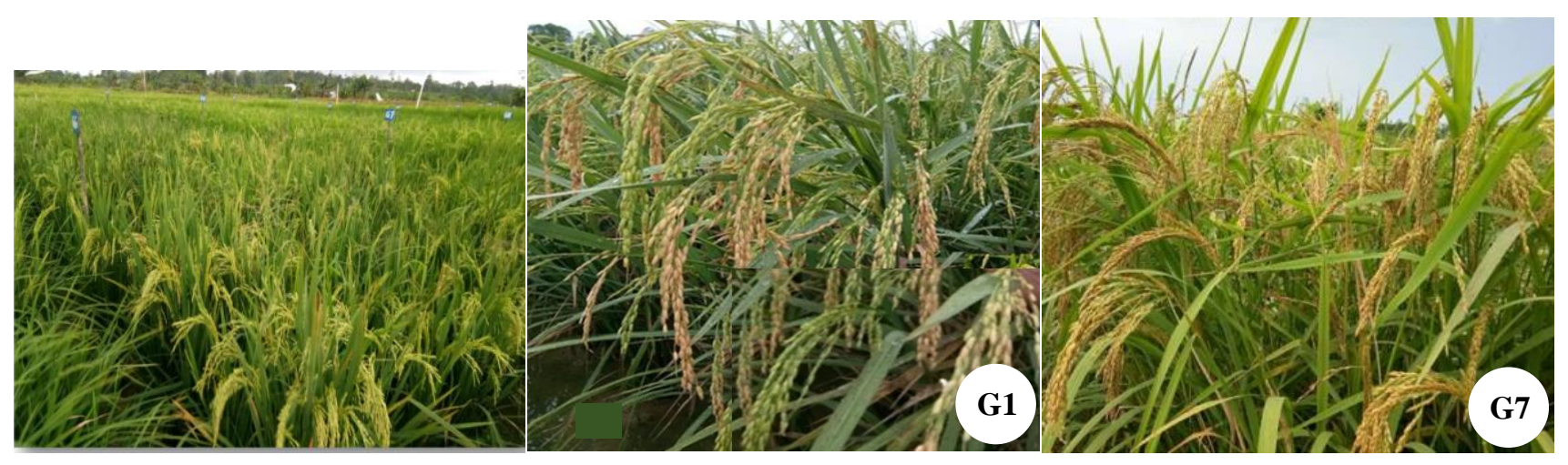

Figure 2. The performance of yield observation experiments in an inland swampy area in Sorong, West Papua. The G1 dan G7 lines are the selected lines that have high yield characters 


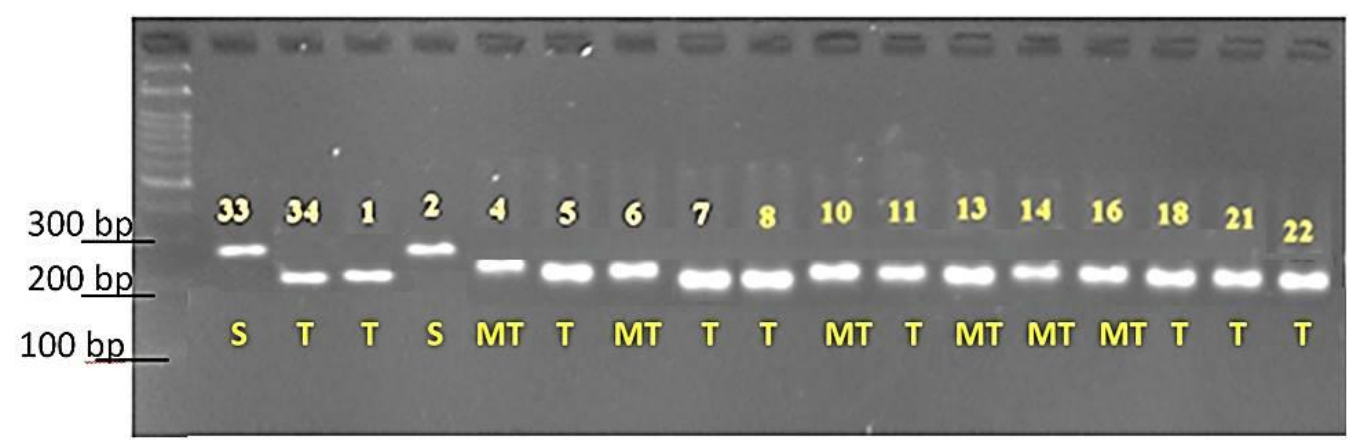

Figure 3. The genotypes performance of the rice lines using the specific marker for $I R T$ gene allele. The allele size was determined using DNA ladder 100 bp marker. Note: $\mathrm{S}=$ Sensitive, $\mathrm{MT}=$ Medium Tolerance, $\mathrm{T}=$ Tolerance

As described before, one of the Fe-toxicity tolerance mechanisms in rice plants was contributed by the IRT (Iron Regulator Transporter) transporter gene. The $\mathrm{Fe}^{2+}$ ions that been absorbed will be transported by the IRT gene to the different parts of the plants, through the mechanism of $\mathrm{Fe}^{2+}$ partitioning so that the plants can be more tolerant to the excessive $\mathrm{Fe}^{2+}$ conditions (Rout et al. 2015). Based on this thoughtful, the tolerance plants will show a low Fe score and have a better on their shoot performance than on the root length. Due to the better root length more indicated having an inclusion regulation on the root level than partitioning mechanism. G1 and G7 are the selected lines that have the better on the shoot than their root length performances. The weight biomass of G1 line (835.3 g) was higher than the tolerance control plant, Mahsuri (G34) $(834.3 \mathrm{~g})$ (Table 5). The G1 line also has a good performance on panicle length $(27.23 \mathrm{~cm})$ closely comparable to the tolerance control plant (Table 5). The genotype performance of G1 and G7 lines showed that they have the lowest size alleles of OsIRT gene (Figure 3). The polymorphism performance between the tolerance and sensitive rice lines obtained by using this marker could be applied for assisting selection. Certainly, this approach has to be supported by the complete phenotype characters related to the target selection. So the associated test between genotype and phenotype characters target could be accomplished.

\section{ACKNOWLEDGEMENTS}

We would like to thank the Tani Maju Lestari farmers group, Makbalim Village, Mayamuk District, Sorong Regency, who helped the authors from the beginning to the end of the study. Also, we would like to thank the Indonesian Center for Agricultural Biotechnology and Genetic Resources (BB-Biogen) for organizing the Sorong inland swamp tolerant rice breeding program. Authors' contributions: AM and DWU: the main contributors who were responsible for designing the research, carrying out the experiments, analyzing-interpreting data, and writing the manuscript. AK, NW, and GW: members contributor who supported data analysis and wrote the manuscript.

\section{REFERENCES}

Aung MS, Masuda H, Kobayashi T, Nishizawa NK. 2018. Physiological and transcriptomic analysis of responses to different levels of iron excess stress in various rice tissues. Soil Sci Plant Nutr 64 (3): 370 385.

Becker M, Asch F. 2005. Iron toxicity in rice-conditions and management concepts. J Plant Nutr Soil Sci 168: 558-573.

Bennett SA, Hansman RL, Sessions AL, Nakamura K, Edwards KJ. 2011. Tracing iron-fueled microbial carbon production within the hydrothermal plume at the Loihi Seamount. Acta 75: 5526-5555.

Doyle JJ, Doyle JL. 1987. A rapid DNA isolation from small amount of fresh leaf tissue. Phytochem Bull 19: 11-15.

Finatto T, de Oliveira AC, Chaparro C, da Maia LC, Farias DR, Woyann LG. 2015. Abiotic stress and genome dynamics: Specific genes and transposable elements response to iron excess in rice. Rice 8 (13): 118. DOI: 10.1186/ s12284-015-0045-6.

Hairmansis A, Kustianto B, Supartopo, Suwarno. 2010. Correlation analysis of agronomic characters and grain yield of rice for tidal swamp areas. Indones J Agric Sci 11 (1): 11-15.

Harahap Z, Silitonga TS. 1998. Perbaikan varietas padi. In: Ismunadji M, Syam M, Yuswadi (eds). Padi, Book 2. Pusat Penelitian dan Pengembangan Tanaman Pangan, Bogor. [Indonesian]

Irawan B. 2005. Konversi lahan sawah: Potensi dampak, pola pemanfaatannya dan faktor determinan. Jurnal Forum Penelitian Agro Ekonomi 23 (21): 1-18. [Indonesian]

Irmawati, Hiroshi E, Rujito AS, Sakagami JI. 2015. Swamp rice cultivation in South Sumatra, Indonesia: An overview. Trop Agr Develop 59 (1): 35-39.

IRRI [International Rice Research Institute]. 2014. Standard Evaluation System for Rice. $4^{\text {th }}$ edition. International Rice Research Institute, Los Banos, Philippines.

Koesrini SM, Nurzakia S. 2018. Adaptasi agronomi padi unggul varietas Inpara pada lahan rawa pasang surut. Jurnal Penelitian Tanaman Pangan 2 (2): 77-83. [Indonesian]

Kustianto B. 2009. Produktivitas galur harapan padi di lahan pasang surut dan rawa Lebak. Jurnal Penelitian Pertanian Tanaman Pangan 28 (1): 34-38. [Indonesian]

Li R, Meijuan L, Umair A, Shiwei L, Jiaen Z. 2019. Exploring the relationship between yield and yield-related traits for rice varieties released in China from 1987 to 2017. Front Plant Sci 10: 535-543.

Mohanty M, Sinha NK, Reddy KS, Chaudhary RS, Rao AS, Dalal RC, Menzies NW. 2013. How important is the quality of organic amendments in relation mineral $\mathrm{N}$ availability in soils? Agric Res 2 (2): 99-110.

Mulyani A, Nursyamsi D, Syakir M. 2017. Strategi pemanfaatan sumberdaya lahan untuk pencapaian swasembada beras berkelanjutan. Jurnal Sumberdaya Lahan 11 (1): 11-22. [Indonesian]

Müller C, Silveira SFD, Daloso DM, Mendes GC, Merchant A, Kuki KN. 2017. Ecophysiological responses to excess iron in lowland and upland rice cultivars. Chemosphere 189: 123-133. DOI: 10.1016/j.chemosphere. 2017.09.033.

Naylor RL, Battisti DS, Vimont DJ, Falcon WP, Burke MB. 2007. Assessing risks of climate variability and climate change for Indonesian rice agriculture. Proc Natl Acad Sci USA 104: 7752-7757. 
Noor M. 2007. Rawa Lebak, ekologi, pemanfaatan dan pengembangannya. In: Hakimah Halim (ed). Pertanian Rawa Lebak. Raja Grafindo Persada, Jakarta. [Indonesian]

Nugraha Y, Rumanti AI. 2017. Perakitan varietas padi toleran keracunan besi. Jurnal Iptek Tanaman Pangan 12 (1): 9-24.

Oladosu Y, Rafii MY, Abdullah N, Malek MA, Rahim HA, Hussin G, Latif MA, Kareem I. 2014. Genetic variability and selection criteria in rice mutant lines as revealed by quantitative traits. Sci World J 2014: $1-12$.

Peterson RG. 1994. Agricultural Field Experiment Design and Analysis. Marcel Dekker, Inc., New York.

Quinet M, Vromman D, Clippe A, Bertin P, Lequeux H, Dufey I. 2012. Combined transcriptomic and physiological approaches reveal strong differences between short- and long-term response of rice (Oryza sativa) to iron toxicity. Plant Cell Environ 35: 1837-1859. DOI 10.1111/j.1365-3040.2012.02521.

Rout GR, Sahoo S. 2015. Role of iron in plant growth and metabolism. Rev Agric Sci 3: 1-24.

Singh BP, Das M, Prasad RN, Ram M. 1992. Characteristics of Fe toxic soils and affected plants and their correction in acid Haplaquents of Meghalaya. Int Rice Res Newsl 17: 18-19.

Suhartini T. 2004. Perbaikan varietas padi untuk lahan keracunan Fe. Buletin Plasma Nutfah 10 (1): 1-11. [Indonesian]

Sulaiman AA, Sulaeman Y, Minasny B. 2019. A framework for the development of wetland for agricultural use in Indonesia. Resources 8 (34): 1-16.

Stein RJ, Ricachenevsky FK, Fett JP. 2009. Differential regulation of the two rice ferritin genes (OsFER1 and OsFER2). Plant Sci 177: $563-$ 569.

Stein RJ, Duarte GL, Scheunemann L, Sophr MG, Junior ATA, Ricachenevsky FK, Rosa LMG, Zanchin NIT, Santos RP, Fett JP. 2019. Genotype variation in rice (Oryza sativa L.) tolerance to $\mathrm{Fe}$ toxicity might be linked to root cell wall lignification. Front Plant Sci 10: 1-20. DOI: $10.3389 /$ fpls.2019.00746.

Utami DW. 2018. Teknologi pemuliaan molekuler dukung optimalisas pertanian lahan rawa. In: Sabran M, Lestari EG, Utami DW,
Purnamaningsih R, Suryadi Y, Tasma IM, Mastur, Sustiprijatno, Wibisono RAS (eds). Pemanfaatan SDG dan Bioteknologi untuk Mendukung Pertanian Berkelanjutan. IAARD Press, Jakarta. [Indonesian]

Utami DW, Rosdianti I, Subardi, Nurani S, Suwarno. 2020. Identification of candidate $\mathrm{Fe}$ tolerance loci in rice (Oryza sativa) determined through Genome-Wide Association Study (GWAS). Indon J Agric Sci 21 (1): 17-29.

Vert G, Briat JF, Curir C. 2001. Arabidopsis IRT2 gene encodes a rootperiphery iron transporter. Plant J 26: 181-189.

Virmani SS. 1977. Varietal tolerance of rice to iron toxicity in Liberia. Int Rice Res Newsl 2: 4-5.

White RE. 2005. Principles and Practices of Soil Science: The Soil as A Natural Resource. $4^{\text {th }}$ edition. John Wiley and Sons Ltd., Chichester, UK.

Widjaja-Adhi IPG, Nugroho K, Ardi D, Karim AS. 1992. Sumber daya lahan rawa: Potensi, keterbatasan dan pemanfaatannya. In: Sutjipto P, Syam M (eds). Prosiding Nasional Pengembangan Pertanian Lahan Rawa Pasang Surut dan Lebak. Badan Penelitian dan Pengembangan Pertanian. Departemen Pertanian, Cisarua, Bogor, 3-4 Maret [Indonesian]

Wu LB, Shhadi M, Gregorio G, Matthus E, Becker M, Frei M. 2014. Genetic and physiological analysis of tolerance to acute iron toxicity in rice. Rice 7 (8): 1-12. DOI: 10.1186/s12284-014-0008-3.

Wu LB, Ueda Y, Lai SK, Frei M. 2017. Shoot tolerance mechanisms to iron toxicity in rice (Oryza sativa L.). Plant Cell Environ 40: 570-584. DOI: $10.1111 /$ pce. 12733 .

Ye Q, Zhang H, Wei H, Zhang Y, Wang B, Xia K, Hou Z, Dai Q, Xu K. 2007. Effect of nitrogen fertilizer on nitrogen use efficiency on yield of rice under different soil conditions. Front Agr China 1 (1): 30-36.

Zhang Y, Xu YH, Yi HY, Gong JM. 2012. Vacuolar membrane transporters OsVIT1 and OsVIT2 modulate iron translocation between flag leaves and seeds in rice. Plant $\mathrm{J}$ 72: 400-410. DOI: 10.1111/j.1365-313X.2012.05088.x. 